\title{
原子吸光法による食品中スズの簡易定量法
}

\author{
(昭和 46 年 8 月 20 日受理)
}

白石麖子* 葛原由章* 末永泉二*

\section{Determination of Tin in Food by Atomic Absorption Spectrophotometry}

\author{
Yoshiko SHIRAISHI, Yoshiaki KUZUHARA, Senji SUENAGA
}

(The Institute of Public Health: 6-1, Shirokanedai 4-chome, Minato-ku, Tokyo,)

The concentration of tin in foods sufficient to cause poisoning is from 50 to $100 \mathrm{ppm}$, rather higher as compared with those of other metals. So, the present study was attempted to develop a simple method for not the determination of the tin in low concentrations but the determination of the metal within a concentration of 50 to $100 \mathrm{ppm}$ and over by Atomic Absorption Spectrophotometry, utilizing a slot burner and acetylene-air flame.

For the purpose of comparison, colorimetric determination was also carried out using salicylidenamino-2-thiophenol, as had been recently reported by Gregory.

The foods tested (canned fish, corned beef and fruit juice) were ashed either by dry ashing in an electric furnace or in a low-temperature dry ashing device, extracted with hydrochloric acid and them estimated directly at $2863 \AA$.

The recovery rate of tin by the dry ashing was 92 to $103 \%$, while that by the low temperature ashing was less than $50 \%$. In the latter case, extraction with alkaline eleratet the recovery to as high as $90 \%$. The recovery rate by the colorimetric method was 80 to $91 \%$.

In the Atomic Absorption Spectrophotometry, the effects of various coexistent substances were less apparent when acetylene-air flame was used instead of hydrogen-air flame.

(Received August 20, 1971)

\section{まえがき}

原子吸光法による食品中スズの定量は, 主に果汁かん 詰が対象になっており, 測定法にはT字型長吸収管を用 いる方法"1)， ヘテュバーナーを用いる方法" があるが， いずれも水素一空気フレームを用い感度を上げて行なっ ている.

食品衛生上でスズによる中毒が問題となる場合, その スズ量は他の金属に比べると，かなり大量で， 50 １00 $\mathrm{ppm}$ 以上が問題である.

われわれは, 対象を魚, 肉および果汁のかん詰食品と し，低濃度のスズの定量よりも，50 100 ppm 以上の中

* 国立公衆衛生院衛生薬学部：東京都港区白金台 46-1
毒量におよぶスズが存在するかどうかを，簡易的に定量 することを目的として，スロットバーナーによるアセチ レンー空気フレームを用いる原子吸光分析法について娭 討を行なった.

また別に, 機器によらない比色分析法として最近報告 された salicylidenamino-2-thiophenol による比色分 析法3) も併せて行ない, 比較検討を行なったので報告す る.

\section{実験方法}

1. 装

日立 207 型原子吸光分析計

光源ランプ：日立社製スズ中空陰極ランプ

然料：アセチレン. 助然剤として空気を使用. 
Table 1. Operating Condition for the Determination of Tin by Atomic Absorption Spectrophotometry

(Instrument: HITACHI 207 Type)

\begin{tabular}{lc}
\hline Light source & HITACHI Hollow Cathoe Lamp \\
Wave length & Sn $2863 \AA$ \\
Lamp current & $13 \mathrm{~mA}$ \\
Air pressure & $1.8 \mathrm{~kg} / \mathrm{cm}^{2}$ \\
Air flow-rate & $13.5 \mathrm{~L} / \mathrm{min}$ \\
Acetylene pressure & $0.5 \mathrm{~kg} / \mathrm{cm}^{2}$ \\
Acetylene flow rate & $4.5 \mathrm{~L} / \mathrm{min}^{2}$ \\
Absorption sense & 20 \\
Burner & slot burner \\
Burner position & 1 \\
\hline
\end{tabular}

バーナー：スロットバーナー

低温灰化装置: International Plasma 社製 IPC-1101 2. 測定条件

測定は Table 1 に示す条件で行なった。

\section{3. 試験溶液の調製}

3-a. 電気炉灰化法: 試料約 $10 \mathrm{~g}$ を正確に科り, パイレックスビーカーにとり, $60 \sim 70^{\circ}$ のホットプレー ト上にのせ, 赤外線ランプ下に水分を蒸発し, さらに炭 化させる.

炭化の終ったビーカーを電気炉に入れ，450 500 に 加熱し完全に灰化させる.

灰分に濃塩酸 $1 \mathrm{ml}$ を加え, ホットプレート上で軽く 加温してとかし，試験管にうつす.

不溶性灰分のあるときは小ガラスフィルターを用いて ろ過する.ビーカーには $0.1 \mathrm{~N}$ 塩酸少量を加えて加温 して洗い，さらにその洗液でガラスフィルターを洗いな がら，洗液をさきの試験管に合わせる．この $0.1 \mathrm{~N}$ 塩 酸による洗浄をくり返し, 全量を $10 \mathrm{ml}$ とする。この液 について直接原子吸光測定を行なう。

3-b. 低温灰化法：最近試料の灰化を行なら場合 に，酸素プラズマによる低温灰化装置が使用されてきて いる. 従来の電気炉による長時間灰化を迅速化し，スズ の揮散防止のため, 低温灰化装置による灰化法も併せて 行なった。

試料約 $10 \mathrm{~g}$ を正確に科り，パイレックスビーカーに とり, $60 \sim 70^{\circ}$ のホットプレート上にのせ, 赤外線ラン プ下に水分を蒸発し, さらに炭化させる. 炭化後ビーカ 一を低温灰化装置に入れ, 酸素流量 $100 \mathrm{ml} / \mathrm{min}, \mathrm{RF}$ Power $150 \mathrm{~W}$ で灰化を行なう。灰分に濃塩酸 $1 \mathrm{ml}$ を加 え，以下 3 - $\mathrm{a}$ に準じて試呀溶液を調製する。

4. スズ標準溶液：金属スズ $0.500 \mathrm{~g}$ に濃塩酸 $30 \mathrm{ml}$ を加え, 時計ザラで覆い, 水浴上に加温してとかし, 冷 後さらに $1 \mathrm{~N}$ 塩酸を用い正確に $500 \mathrm{ml}$ とする。この 液 $1 \mathrm{ml}$ 中には $1000 \mu \mathrm{g}$ のスズを含む。

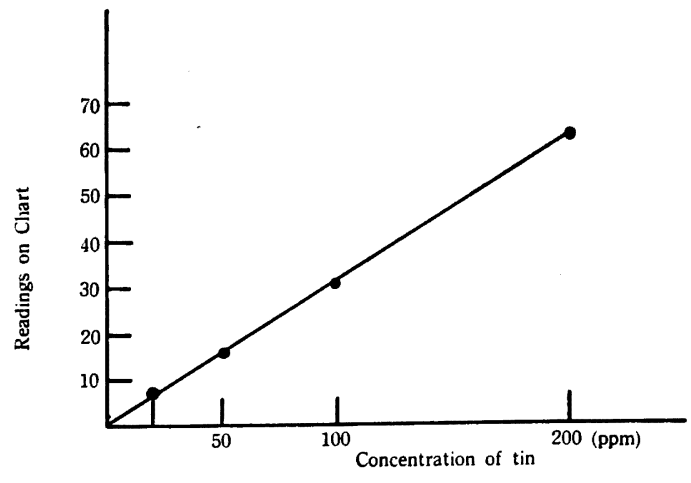

Fig. 1. Calibration Curve for tin

5. 検量線の作製： スズ標準溶液を $1 \mathrm{~N}$ 塩酸を用い てうすめ, 各種濃度のスズ溶液について検量線を求め た. Fig. 1 に示すとおり 10 200 ppm の範囲で直線性 を示した。

\section{実験哧果および考察}

\section{1. 測定精度}

Table 1 に示す測定条件のもとに, スズ $100 \mathrm{ppm}$ 溶 液について10回繰返し測定をおこない，測定精度を求め た. 結果は Table 2 に示すとおり, 変動係数は1.9\%で あった。

Table 2. Reproducibility of Tin Absorbances with the Operating Condition

\begin{tabular}{cc} 
No. & Readings on chart* \\
\hline 1 & 20.5 \\
2 & 21.2 \\
3 & 21.2 \\
4 & 20.5 \\
5 & 21.2 \\
6 & 21.6 \\
7 & 20.5 \\
8 & 20.3 \\
9 & 21.0 \\
10 & 21.2 \\
\hline Mean value & 20.9 \\
Std. deviation & 0.40 \\
Coefficient of variation (\%) & 1.9 \\
$* 100$ ppm tin $1 \mathrm{~N}-\mathrm{HCl}$ soln. &
\end{tabular}

\section{2. 共存物梊の影響}

スズの原子吸光分析における，各種金属および無機酸 の影響についてはすでに報告されているが1)247)，いず れも水素一空気炏によるものである.

上記の 3-a および 3-b の死化法による食品中のス 
Table 3. Effect of the Coexistent Substances on Tin Absorption

\begin{tabular}{|c|c|c|c|}
\hline Coexistent substances & Added $\%$ & Readings on chart & $\%$ to the reference \\
\hline $\begin{array}{l}\text { Reference tin } 100 \mathrm{ppm} \\
1 \mathrm{~N} \mathrm{HCl} \mathrm{Soln.}\end{array}$ & 0 & 19.0 & 100 \\
\hline $\mathrm{NaCl}$ & $\begin{array}{l}0.5 \\
1 \\
2 \\
5\end{array}$ & $\begin{array}{l}19.0 \\
19.0 \\
20.8 \\
22.2\end{array}$ & $\begin{array}{l}100 \\
100 \\
109 \\
117\end{array}$ \\
\hline $\mathrm{CaCl}_{2}$ & $\begin{array}{l}0.1 \\
0.5 \\
1\end{array}$ & $\begin{array}{l}19.3 \\
19.5 \\
19.2\end{array}$ & $\begin{array}{l}102 \\
103 \\
101\end{array}$ \\
\hline $\mathrm{H}_{3} \mathrm{PO}_{4}$ & $\begin{array}{l}0.1 \\
0.5 \\
1\end{array}$ & $\begin{array}{l}19.0 \\
19.2 \\
19.5\end{array}$ & $\begin{array}{l}100 \\
101 \\
103\end{array}$ \\
\hline Sugar & $\begin{array}{r}2 \\
5 \\
10 \\
15\end{array}$ & $\begin{array}{l}19.5 \\
17.8 \\
18.2 \\
16.3\end{array}$ & $\begin{array}{r}103 \\
94 \\
96 \\
86\end{array}$ \\
\hline Tartaric acid & $\begin{array}{r}2 \\
5 \\
10 \\
15\end{array}$ & $\begin{array}{l}20.0 \\
18.2 \\
19.0 \\
16.7\end{array}$ & $\begin{array}{r}105 \\
96 \\
100 \\
88\end{array}$ \\
\hline Citric acid & $\begin{array}{r}2 \\
5 \\
10 \\
15\end{array}$ & $\begin{array}{l}20.0 \\
20.0 \\
19.0 \\
16.0\end{array}$ & $\begin{array}{r}105 \\
105 \\
100 \\
84\end{array}$ \\
\hline
\end{tabular}

ズの測定に際して，食品から由来する共存物質として塩 化ナトリウム，リン酸塩，塩化カルシウムなどの影響が 考えられる。

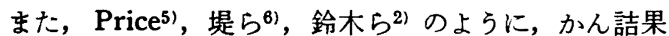
汁について，塩酸酸性においてろ過した液を直接原子吸 光にかける場合には，上記物質のほかに，クェン酸，酒 石酸，ショ糖などが共存するわけである，そこで上記物 質について，アセチレン一空気フレームによる測定の際
の影響について検討した。

Table 3 に示寸とおり，塩化ナトリウムは $2 \%$ 以上の 濃度になると明らかに増感作用を示した。塩化カルシウ ムおよびリン酸は $1 \%$ まではほとんど影響がなく，ショ 糖，クエン酸および酒石酸は10\%までは大きな影響がな かった．以上の結果から, 水素一空気フレームの場合 ${ }^{121}$ に比べ，アセチレンー空気フレームの場台の方が，共存 物質による影響は小さいことを認めた。

Table 4. Analytical Results of Tin from Canned Foods

\begin{tabular}{|c|c|c|c|c|c|c|c|c|}
\hline \multirow{6}{*}{ 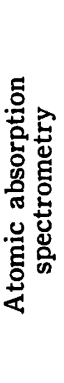 } & \multirow{4}{*}{ 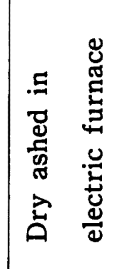 } & Sample & $\begin{array}{l}\text { No. } \\
\text { of runs }\end{array}$ & $\begin{array}{c}\text { Back ground } \\
\text { tin, ppm }\end{array}$ & $\begin{array}{l}\text { Added } \\
\text { tin, ppm }\end{array}$ & $\begin{array}{c}\text { Total tin } \\
\text { found, ppm }\end{array}$ & $\begin{array}{c}\text { Recovery } \\
\%\end{array}$ & $\begin{array}{l}\text { Coefficient of } \\
\text { variation, } \%\end{array}$ \\
\hline & & Salmon & 5 & 29 & 200 & 235 & 103 & 7 \\
\hline & & Corned beef & $\begin{array}{l}3 \\
5\end{array}$ & $\begin{array}{l}12 \\
30 *\end{array}$ & " & $\begin{array}{l}184 \\
225 *\end{array}$ & $\begin{array}{l}92 \\
97 *\end{array}$ & $\overline{6^{*}}$ \\
\hline & & Orange juice & 5 & 28 & " & 229 & 101 & 5 \\
\hline & \multirow{2}{*}{ 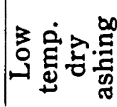 } & Salmon & 5 & 16 & " & 88 & 44 & 4 \\
\hline & & Corned beef & 5 & 9 & " & 95 & 48 & 4 \\
\hline \multirow{3}{*}{\multicolumn{2}{|c|}{ 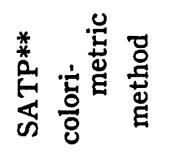 }} & Salmon & 5 & 62 & " & 220 & 79 & 4 \\
\hline & & Corned beef & 5 & 66 & $"$ & 248 & 91 & 15 \\
\hline & & Orange juice & 5 & 96 & " & 255 & 80 & 10 \\
\hline
\end{tabular}

* The results were obtained by standard addition method

** SATP: salicylidenamino-2-thiophenol 


\section{3. かん詰食品中のスズの定量}

市販かん詰のさけ, コンビーフ，オレンジジュースに ついて，スズの定量を行なった。

食品 $10 \mathrm{~g}$ ずつをとり，それぞれ 3-a および 3-bに 準じ前処理を行なったのち，原子吸光測定を行なった。

なお, salicylidenamino-2-thiophenol による比色法 は，3-a に準じて調製した試験溶液について行なった。 かん詰食品中のスズの定量值および食品に添加したス ズの回収率は Table 4 汇示した。

ただし，表中の試料はそれぞれ製造ロットが異なるの で, back ground 值は相互に比較できない.

Table 4 の結果からわかるとおり, 電気炉灰化, 酸抽 出により原子吸光測定を行なった場合，さけ，オレンジ ジュースは標準添加法によらなくても，103および101\% の回収率を示した。コンビーフについては直接定量では 92\%であったが，標準添加法を行なえば97\%の回収率が 得られた。

低温灭化前処理を行なった場合の回収率は低く，44， 48\%を示すのみであった。そこで酸抽出を行なら前に, $30 \%$ 水酸化ナトリウム $1 \mathrm{ml}$ を加えて加温してとかし, 抽出液を小試験管にうつしたのち，1N-塩酸少量ずつを 用いてビーカーを洗い, 全量を $10 \mathrm{ml}$ とし，この液につ いて原子吸光測定を行なった。この結果, さけの場合, 回収率は44\%から86\%に上昇した。

以上のことから, スズの定量に際して, 低温灰化を行 なら場合, 長時間酸素プラズマにさらされる結果, 酸不 溶性酸化物が生成するものと思われる，したがって，低 温灰化の場合に酸抽出は不適当と思われる。

比色定量法として行なった salicylidenamino-2-thiophenol 法の場合は, さけ, コンビーフ,オレンジジュ ースともに80〜91\%の回収率を示した.

\section{まとめ}

食品衛生上で問題になるスズの中毒量程度以上，すな わち $100 \mathrm{ppm}$ 以上のスズを含有する食品を対象とし, もっとも普通のアセチレン一空気フレーム，スロットバ ーナーを用いる原子吸光法による簡易定量法について検 討した。
さけ，コンビーフ，果汁を対象とし，電気炉灰化，塩 酸抽出を行なった液を直接原子吸光にかけた場合, スズ の回収率は 92〜 103\%であった.

アセチレン一空気フレームによる原子吸光法につい て，種々の共存物質の影響を検討したところ，2\%以上 の塩化ナトリウムは明らかに増感作用を示したが，塩化 カルシウム, リン酸, ショ榶, クエン酸, 酒石酸等は低濃 度ではほとんど影響がなかった。すなわち，アセチレン 一空気フレームによる場合, 水素一空気フレームの場合 に比べて，共存物質による影響の小さいことを認めた。

かん詰果汁について，今回は灰化を行なったが，直接 原子吸光測定を行なら場合(2)5)6), 高濃度のショ糖, 酒 石酸, クエン酸の存在による影響があるので, 試料果汁 の適当な希釈を行ならか, または標準添加法を行ならべ きであろら。

酸素プラズマによる低温灰化を行なった場合は，スズ の酸不溶性酸化物の生成により, 塩酸抽出により原子吸 光測定を行ならと $50 \%$ 以下のスズ回収率を示し, アルカ リ抽出を行なえば約 $90 \%$ まで上昇した。

電気炉灰化, 塩酸抽出後, salicylidenamino-2-thiophenol による比色法を行なった場合，スズの回収は 80 〜91\%を示した。

文献

1) 岡田敏史, 志村 博, 吉村 淳, 寺島敏雄: 衛 生化学 15, 351 (1969).

2)鈴木健次郎, 森 光国: 食衛誌. 12, 4 (1971).

3) Gregory, G.R.E.C., Jeffery, P. G.: Analyst 92, 293 (1967).

4) Juliano, P. O., Harrison, W. W.: Anal. Chem. 42, 84 (1970).

5) Price, W. J., Roos, J. T. H.: J. Sci. Food Agric. 20, 437 (1969).

6）堤 忠一, 入山宏正, 小曾戸和夫：日本食品工 業学会第16回発表講演要旨.

7) Levine, J. R., Moore, S. G., Levine, S. L.: Anal. Chem. 42, 412 (1970). 